American Journal of Applied Sciences 6 (8): 1553-1559, 2009

ISSN 1546-9239

(C) 2009 Science Publications

\title{
Meltability and Stretchability of White Brined Cheese: Effect of Emulsifier Salts
}

\author{
${ }^{1}$ Khaled Abu-Alruz, ${ }^{2}$ Ayman Suliman Mazahreh, ${ }^{3}$ Ali F. Al-Shawabkeh, \\ ${ }^{4} \mathrm{Amer}$ Al Omari and ${ }^{5}$ Jihad M. Quasem \\ ${ }^{1}$ Department of Food Science and Nutrition, Faculty of Allied Medical Sciences, \\ Applied Science University, Amman, Jordan, \\ ${ }^{2}$ Department of Applied Sciences, Al-Balqa Applied University, \\ Princes Alia University College, P.O. Box 941941, Amman 11194, Jordan \\ ${ }^{3}$ Department of Basic Sciences, Faculty of Engineering Technology, \\ Al-Balqa Applied University, P.O. Box 15008, Amman 11134, Jordan \\ ${ }^{4}$ Al-Balqa' Applied University, Ajloon University College, Ajloon-Jordan \\ ${ }^{5}$ Department of Medical Allied Science, Al-Balqa Applied University, \\ Zarqa University College, Zarka, Jordan
}

\begin{abstract}
Problem statement: This study was based on the hypothesis that by adding low concentrations of emulsifier salts, may specifically act on the cross linking bonds of the protein matrix, to the original brine (storage medium) it would be possible to induce meltability and stretchability in white brined cheese. Approach: A new apparatus for measuring the actual stretchability was designed and constructed; measurements on different cheese samples proved its validity and reliability to measure stretchability. The apparatus was used to evaluate the effect of five types of emulsifier salts under different processing conditions.Results: It was found that by adding $0.2 \%(\mathrm{w} / \mathrm{w})$ Puromelt $\mathrm{C} 1$ or Monosodium phosphate to the brine of white brined cheese, higher levels of stretchability and meltability were induced after 2-4 weeks of storage. Conclusion: Addition of emulsifying salts was proved to be effective method in inducing meltability and stretchability of white brined cheese. Type of salt, its concentration, type of cheese and soaking time are factors that should be controlled to attain the optimum results.
\end{abstract}

Key words: White brined cheese, Nabulsi cheese, emulsifier salt, stretchability and meltability

\section{INTRODUCTION}

One of the most widely produced cheese types in the Mediterranean, south east European and Middle Eastern countries is white brined cheese ${ }^{[3]}$. This type of cheese is highly consumed in many ways, e.g., for breakfast, as a snack or as an essential ingredient in some traditional sweets ${ }^{[2]}$. White brined cheeses are mainly produced from sheep milk, but are sometimes made from goat or cows' milk, or a mixture of both ${ }^{[6]}$. The composition of white brined cheese varies considerably depending on the method of manufacture, type of milk and seasonal changes ${ }^{[3]}$.

White brined cheese is classified as a semi-hard cheese (moisture content 45-55\%). It is boiled in brine for preservation purposes ${ }^{[2]}$. Salt contributes directly to the cheese flavor and controls the multiplication and metabolism of the microorganisms ${ }^{[5]}$. In addition to enhancing cheese taste the concentration and distribution of salt in cheese have a major influence on various aspects of cheese quality including texture ${ }^{[4]}$. The salt concentration of the brine differs from one variety of cheese to another and also depends upon whether the brined cheese is to be stored for long or short periods of time ${ }^{[3]}$. The keeping ability of white cheese is mainly dependent on the salt concentration of the storage medium (brine) and boiling of the cheese before storage in cans ${ }^{[2]}$. Partial desalting of white brined cheese makes it suitable for consuming for breakfast, as a snack or as an ingredient in the preparation of local traditional dishes and sweets ${ }^{[6]}$. One of the most important functional characteristics of importance in sweets preparation includes meltability and stretchability ${ }^{[8]}$.

Corresponding Author: Ayman Suliman Mazahreh, Department of Head of Applied Sciences, Al-Balqa Applied University, Princes Alia University College, P.O. Box 941941, Amman 11194, Jordan 
The original method of white brined cheese processing does not include any steps, or efforts, to introduce meltability and stretchability, such characteristics when found in white brined cheese are rather incidental. Proper control of cheese meltability requires objective and accurate measurement of the property $^{[12]}$. Many attempts have been made to measure meltability in specific, objective and physical terms but none have been entirely successful. Smith et al. ${ }^{[10]}$ determined the flow curve of Mozzarella cheese at several temperatures by a capillary viscometer, but slippage and strong viscoelastic effects played a dominant role, making it impossible to obtain meaningful rheological data. Another method was studying quality of cheese with a Differential Scanning Calorimeter (DSC). However, the DSC data were not useful in predicting melting behavior of cheese ${ }^{[9]}$.

Emulsifying agents (melting salts) are of major importance in processed cheese production; they are used to provide a uniform structure during the melting process. Phosphates, polyphosphate and citrate are some of the most common emulsifying salts used in processed cheese $^{[7]}$. The essential role of the emulsifying agents in the manufacturing of processed cheese is to supplement the emulsifying capability of cheese proteins. This is accomplished by removing calcium from the proteins; peptizing, solubilizing and dispersion of the proteins; hydrating and swelling of the proteins; emulsifying of fat and stabilizing of the emulsion and by forming an appropriate structure after cooling ${ }^{[11]}$.

To date, there are no studies on the addition of small amounts of emulsifier salts to white brined cheese, or other types of brined cheeses, to enhance the meltability and stretchability without heat treatment, or other manipulation of the processing or storage conditions. Therefore, the aims of this study were to experimentally determine the effect of emulsifier salts (melting salts) on the stretchability and meltability of local white brined cheese and to evaluate the treatments by a new developed instrument.

\section{MATERIALS AND METHODS}

Experimental cheese samples: Freshly drawn, cows' and sheep milk was obtained from a local farm in the northern part of Jordan to produce white brined cheese. The traditional method for the production of this kind of cheese was followed, as shown in Fig. 1, using renneting technique (Rennilase) instead of culturing.

Emulsifier salts (melting salts): Five emulsifier salts were selected to test their ability to modify meltability and stretchability of the brined white cheese.

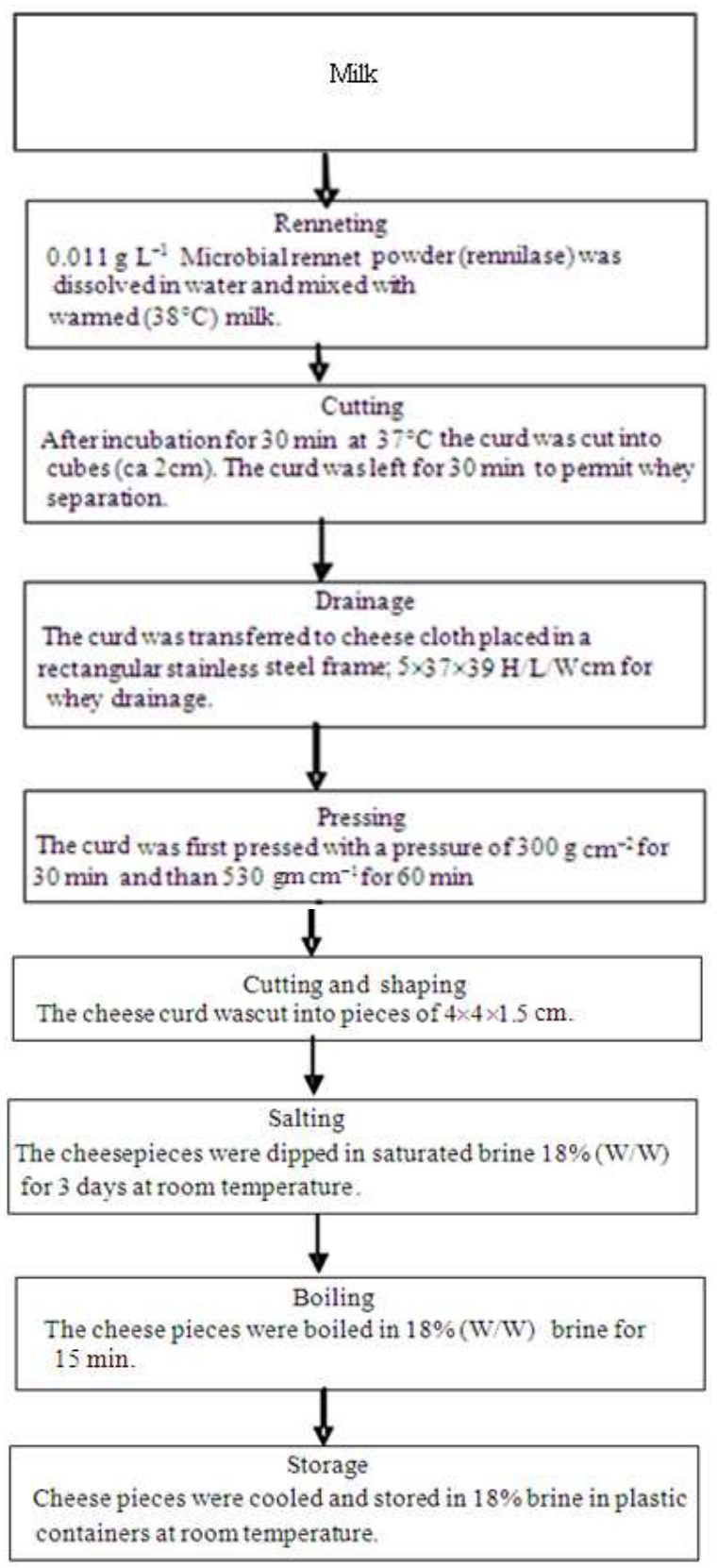

Fig. 1: Processing steps for the production of experimental white brined Nabulsi cheese

The emulsifier salts used in the investigation with their contents and sources were: (1) Joha SE (Sodium diphosphate and Sodium polyphosphate) (BK Giulini GmbH, Ludwigshafen, Germany). (2) Abastol 305 (Sodium diphosphate and Sodium triphosphate) (BK Giulini GmbH, Ludwigshafen, Germany). (3) Puromelt ES1 (Triphosphate, Sodium poly phosphate and Sodium phosphate) (Rhodia UK Ltd, Watford, UK). (4) 
Puromelt C1 (Sodium citrate, Sodium phosphate and Sodium polyphosphate) (Rhodia UK Ltd, Watford, UK). (5) Monosodium Phosphate (MSP) (Sodium dihydrogen phosphate) (Sigma Chemical Company, St Louis, MO, USA).

Experiments were first conducted on white brined cheese samples prepared from cows' milk. The boiled brined cheese cube $(2 \times 2 \times 1.5 \mathrm{~cm})$ samples weighing $72 \mathrm{~g}$ $( \pm 0.5 \mathrm{~g})$ each were placed into $500 \mathrm{~mL}$ glass containers with $425 \mathrm{~mL}$ of $18 \%(\mathrm{w} / \mathrm{w})$ brine solution. A $2.5 \mathrm{~g}$ of each dry emulsifier salt was added to each container $(0.5 \%(\mathrm{w} / \mathrm{w}))$. The meltability and stretchability of the treated and untreated (control) cheese samples kept at room temperature were measured each day for the duration of 1 week. Each treatment was performed in triplicate.

Puromelt C1 and Monosodium phosphate: The two emulsifier salts, Puromelt C1 and Monosodium phosphate, were further tested as described previously. However, in this experiment different emulsifier salt concentrations $(0.2,0.5$ and $0.8 \%(\mathrm{w} / \mathrm{w}))$ and three types of white brined cheese (cows', sheep and mashmouleh) were used. The meltability and stretchability of the treated and untreated cheese samples were measured at 1 week intervals for 4 weeks at room temperature. Each treatment was performed in triplicate.

Effect of Puromelt $\mathrm{C} 1$ concentrations and long-term storage on meltability and stretchability of white brined cheese: Four different concentrations $(0.1,0.2$, 0.4 and $0.8 \%(\mathrm{w} / \mathrm{w}))$ of Puromelt Clemulsifier salt were used in this experiment following the procedure described previously. The meltability and stretchability of the treated and untreated white brined cheese, prepared from sheep milk, were measured at 1 week intervals for 8 weeks. Each treatment was performed in triplicate.

\section{Testing methods:}

Meltability test: The method used to measure the meltability of cheese was described by Arnott et al. ${ }^{[1]}$. It is based on heating a standardized cylindrical cheese specimen, followed by measuring the specimen's diameter. This was carried out as follows. Cylindrical samples of $2 \mathrm{~cm}$ diameter and $1.5 \mathrm{~cm}$ height were cut from a desalted (soaked in distilled water over night) cheese sample using a test tube of $2 \mathrm{~cm}$ diameter. The specimen was wrapped again and stored at $4{ }^{\circ} \mathrm{C}$ until testing. The cheese specimen was placed on a Petri-dish and heated at $100^{\circ} \mathrm{C}$ in a conventional oven (Binder, ED 115, Tuttlingen, Germany) for 15 min. Following this, the diameter of the specimen was measured.

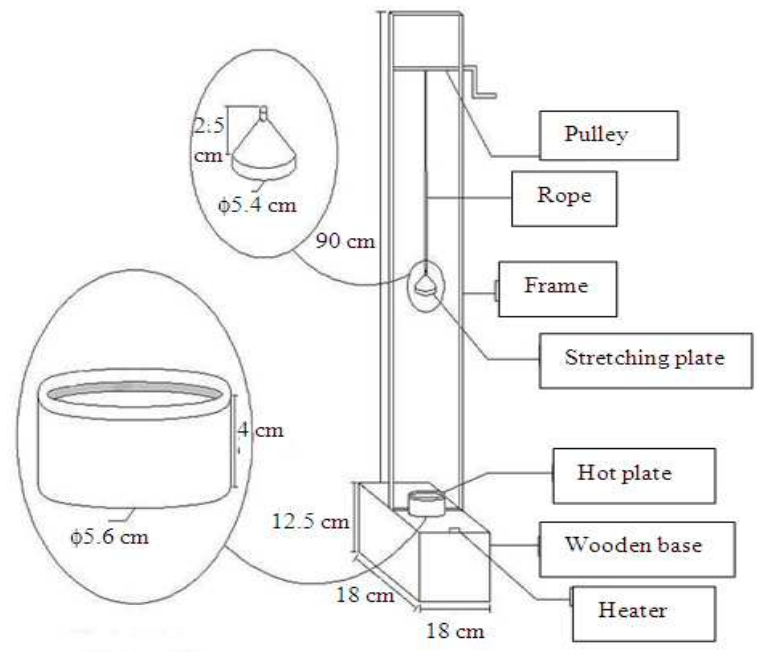

Fig. 2: Schematic diagram of the new apparatus for stretchability measurement

Stretchability test: A new apparatus for measuring the stretchability of cheese was designed and constructed. It is based on heating a specified amount of cheese on a thermostatically controlled hot plate, followed by measuring the distance between the hot plate and moveable stretching plate before the cheese strands are torn off.

Figure 2 shows a schematic diagram of the new apparatus. It consists of a base with a thermostatically controlled hot plate and a moveable stretching plate, weighing $400 \mathrm{~g}$, which hangs above the hot plate on a metal frame $(18 \mathrm{~cm}$ width and $90 \mathrm{~cm}$ height). The stretching plate is lifted and lowered via a pulley with a rope. Both plates were mantled before every measurement with filter paper fixed by tight aluminum rings (Fig. 2). A desalted $15 \mathrm{~g}$ cheese sample was manually disintegrated using a spatula and spread evenly over the filter paper on the hot plate surface and preheated to $80^{\circ} \mathrm{C}$ for $40 \mathrm{sec}$. The stretching plate was lowered until it met the heated sample and then held for $5 \mathrm{sec}$. The stretching plate was then lifted at a constant rate $\left(2 \mathrm{~cm} \mathrm{sec}^{-1}\right)$ until the stretched cheese strands were torn off. The distance between the two plates in $\mathrm{cm}$ is considered as a measure of stretchability. Each treatment was performed in triplicate.

Analysis of pH: The $\mathrm{pH}$ value of selected samples was measured using a $\mathrm{pH}$ meter (CyberScan $\mathrm{pH} 11$, Wagtech Int., Berkshire, UK). A well-homogenized $10 \mathrm{~g}$ cheese sample was mixed using a blender with $6 \mathrm{~mL}$ deionized water to form a fine suspension in which the electrode of the $\mathrm{pH}$-meter was immersed. 
Am. J. Applied Sci., 6 (8): 1553-1559, 2009

Table 4: Effect of puromelt $\mathrm{C} 1$ and monosodium phosphate at different concentrations on stretchability of three Nabulsi cheese varieties, stored for four weeks

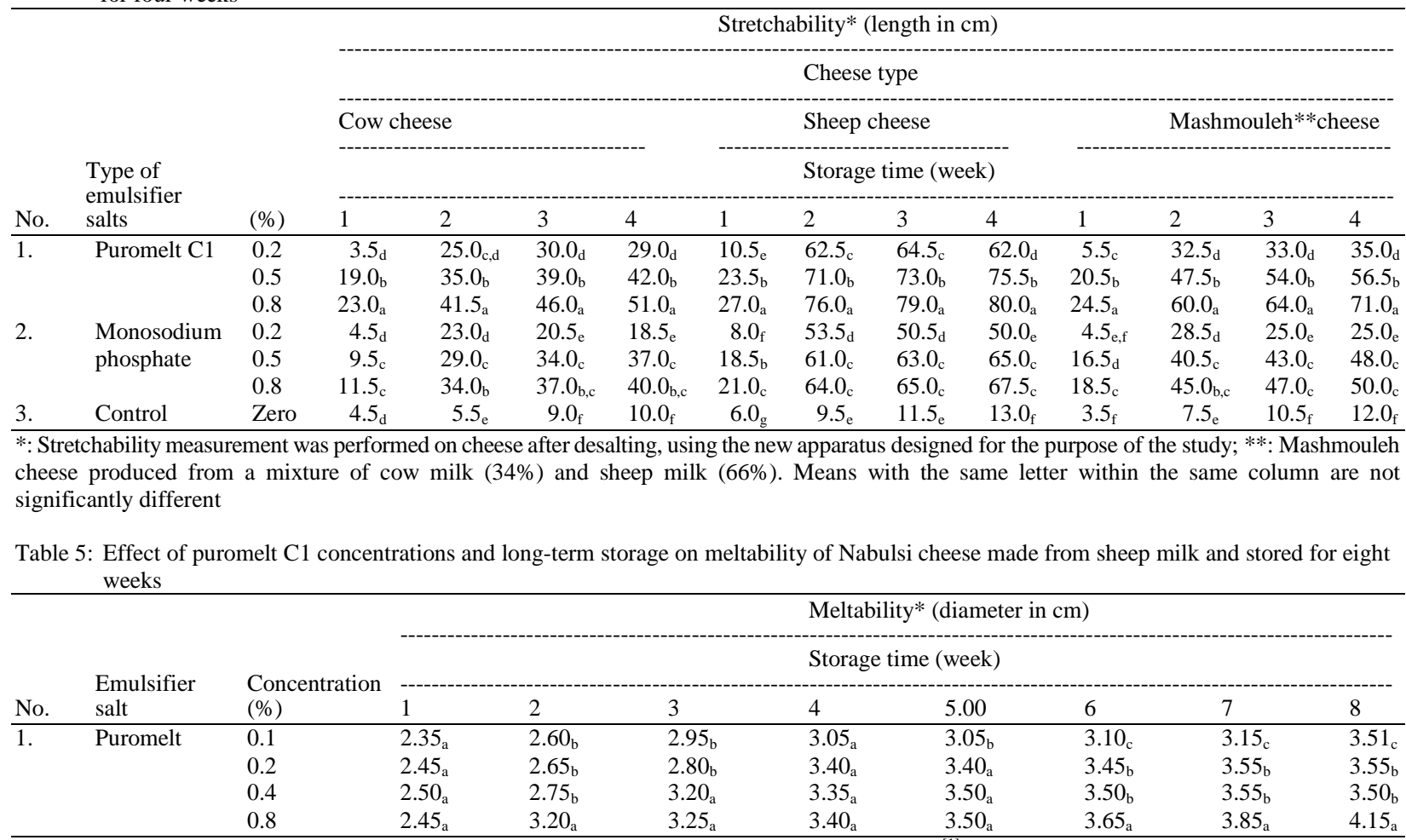

*: Meltability measurements was performed on the cheese after desalting, using Arnott method ${ }^{[1]}$. Means with the same letter within the same column are not significantly different

Table 6: Effect of puromelt $\mathrm{C} 1$ concentrations and long-term storage on stretchability of Nabulsi cheese made from sheep milk and stored for eight weeks

\begin{tabular}{|c|c|c|c|c|c|c|c|c|c|c|}
\hline \multirow[b]{3}{*}{ No. } & \multirow{3}{*}{$\begin{array}{l}\text { Emulsifier } \\
\text { salt }\end{array}$} & \multirow{3}{*}{$\begin{array}{l}\text { Concentration } \\
(\%)\end{array}$} & & \multicolumn{7}{|c|}{ Stretchability* (length in $\mathrm{cm}$ ) } \\
\hline & & & \multicolumn{8}{|c|}{ Storage time (week) } \\
\hline & & & 1 & 2 & 3 & 4 & 5 & 6 & 7 & 8 \\
\hline \multirow[t]{4}{*}{1.} & Puromelt & 0.1 & $11.5_{\mathrm{c}}$ & $51.0_{\mathrm{d}}$ & $47.5_{c}$ & $50_{\mathrm{d}}$ & $47.5_{d}$ & $46_{d}$ & $45.0_{\mathrm{d}}$ & $46.5_{d}$ \\
\hline & & 0.2 & $12.5_{\mathrm{c}}$ & $62.5_{\mathrm{c}}$ & $65.5_{\mathrm{b}}$ & $63_{\mathrm{c}}$ & $60.0_{\mathrm{c}}$ & $61_{c}$ & $59.5_{\mathrm{c}}$ & $61.0_{\mathrm{c}}$ \\
\hline & & 0.4 & $19.0_{\mathrm{b}}$ & $67.0_{\mathrm{b}}$ & $70.0_{\mathrm{b}}$ & $72_{b}$ & $73.5_{b}$ & $72_{b}$ & $73.0_{\mathrm{b}}$ & $72.5_{b}$ \\
\hline & & 0.8 & $25.5_{\mathrm{a}}$ & $73.5_{\mathrm{a}}$ & $78.0_{\mathrm{a}}$ & $80_{\mathrm{a}}$ & $80.0_{\mathrm{a}}$ & $80_{\mathrm{a}}$ & $80.0_{\mathrm{a}}$ & $80.0_{\mathrm{a}}$ \\
\hline
\end{tabular}

*: Stretchability measurements was performed on the cheese after desalting, using the new apparatus designed for the purpose of the study.

Means with the same letter within the same column are not significantly different

Effect of Puromelt C1 concentrations and long-term storage on meltability and stretchability of white brined cheese: Table 5 and 6 show the effect of puromelt $\mathrm{C} 1$ concentration and storage time on meltability and stretchability of Nabulsi cheese from sheep milk respectively. It is obvious from the results that the optimum stretchability values were reached at the end of the third week of storage whereas the meltability tended to steadily increase specially at the highest emulsifier salt concentration $(0.8 \%(\mathrm{w} / \mathrm{w}))$.

Effect of four selected emulsifier salts on $\mathrm{pH}$ changes of Nabulsi cheese from cow milk: Table 7 shows the effect of Joha SE, Abastol 305, Puromelt C1 and
Monosodium phosphate emulsifier salts on the $\mathrm{pH}$ of a white brined cheese prepared from sheep milk at $0.5 \%$ $(\mathrm{w} / \mathrm{w})$ concentration. The shift of cheese $\mathrm{pH}$ was less than the nominal ranges given by the suppliers.

\section{DISCUSSION}

Effect of emulsifier salts on white brined cheese from cows' milk. This experiment was performed to test the effectiveness of five emulsifier salts and to select the most promising ones for further studies. The concentration of the emulsifier salts added was at low level $(0.5 \%)(\mathrm{w} / \mathrm{w})$ compared to the concentrations 
Am. J. Applied Sci., 6 (8): 1553-1559, 2009

added to processed cheese in order to affect a balance between stretchabiity and meltability. Higher concentration would lead to high meltability (fluidity) which counteracts stretchability. According to the results shown in Table 1 and 2 and after 7 days of storage, Abastol 305 had the highest meltability values (3.75); at the same time, it had the lowest stretchability value (11.5) when compared with the other emulsifier salts, whereas puromelt $\mathrm{C} 1$ had the lowest meltability value (2.75), when compared with the other emulsifier salts and at the same time had the highest stretchability value (20). Accordingly, selecting the best emulsifier salts will depend mainly on stretchability values since stretchability as measured by our instrument will never be achieved without having a certain level of meltability. According to the results obtained from Table 1 and 2, puromelt $\mathrm{C} 1$ and mono sodium phosphate were selected for further investigation.

Effect of Puromelt C1 and Monosodium phosphate at different concentrations on three white brined cheese varieties, stored for 4 weeks: Table 3 and 4 show that any of the concentrations used is practical for application, for a treatment duration of three weeks, but higher storage time may cause lyses of the cheese in the case of monosodium phosphate as indicated by increased meltability values at the end of the fourth week. The action of emulsifier salts is summarized in peptizing, solubilizing dispersion of caseins and removing calcium from the proteins that results in replacement of cross linking polyvalent cations by monovalent ones ${ }^{[4]}$. This leads to isolation of the peptide chains and/or of the paracasein sub micelles that will induce meltability and possible stretchability of the cheese ${ }^{[8]}$. However, a successful treatment as targeted in this study should achieve a restricted balanced action that avoids high meltability at the cost of stretchability. Therefore, the lowest concentration $(0.2 \%(\mathrm{w} / \mathrm{w}))$ is preferable and at the same time more economic. The results obtained in this experiment revealed high success in inducing meltability and stretchability to a cheese which is originally do not have such characteristics, so that it becomes superior to the different Mozzarella cheese samples tested under similar conditions (data not shown). From the results shown in Table 3 and 4, sheep cheese gave the best results and therefore the investigation process was continued using sheep cheese and puromelt $\mathrm{C} 1$. Based on the results of this experiment, another experiment was designed to investigate the effect of long term storage on meltability and stretchability of white brined cheese of the Nabulsi type (made from sheep milk) using puromelt $\mathrm{C} 1$ added at low concentrations.
Table 7: Effect of four selected emulsifier* salts $(0.5 \%)$ at equilibrium $\mathrm{pH}$ of Nabulsi cheese made from cow milk

\begin{tabular}{|c|c|c|c|c|}
\hline No. & $\begin{array}{l}\text { Emulsifier } \\
\text { salt }\end{array}$ & $\begin{array}{l}\text { Nominal** } \\
\text { pH range of } \\
\text { emulsifier } \\
\text { salt }\end{array}$ & $\begin{array}{l}\mathrm{pH} \text { of the } \\
\text { cheese before } \\
\text { treatment with } \\
\text { emulsifier salt }\end{array}$ & $\begin{array}{l}\mathrm{pH} \text { changes } \\
\text { after treatment } \\
\text { with emulsifier } \\
\text { salt }\end{array}$ \\
\hline 1 & Joha SE & $7.5-9$ & 6.6 & 7.3 \\
\hline 2 & Abastol 305 & $8-9$ & 6.6 & 7.4 \\
\hline 3 & Puromelt C1 & $7.5-9$ & 6.6 & 7.6 \\
\hline 4 & $\begin{array}{l}\text { Monosodium } \\
\text { phosphate }\end{array}$ & 4.3-4.8 & 6.6 & 6.4 \\
\hline 5 & Control & - & 6.6 & 6.6 \\
\hline
\end{tabular}
$*:$ Effect of the added salt calculated
brine); $* *$ : As given by the supplier

Effect of Puromelt C1 concentrations and long-term storage on meltability and stretchability of white brined cheese: The main goals of this experiment were to find out the optimum storage (soaking) time of puromelt $\mathrm{C} 1$ at different concentrations as indicated by the highest stretchability values and to explore the longterm storage effect on meltability and stretchability. It is worth to remention that the cheese pieces stored for this study were of $(2 \times 2 \times 1.5 \mathrm{~cm})$ dimensions, that means a layer thickness of $1.5 \mathrm{~cm}$. Decreasing the layer thickness will significantly decrease the equilibrium time, whereas increasing the layer thickness will exponentially increase the equilibrium time (Humeid,et.al. 1990). It is thought that the diffusion rate is the major limiting factor of the process. From practical point of view, it can be concluded that the targeted stretchability of Nabulsi cheese can be achieved after two weeks of storage from addition of a $0.1 \%(\mathrm{w} / \mathrm{w})$ puromelt $\mathrm{C} 1$ to the cheese in its original brine. In all cases a stretchability test on a desalted cheese sample should be carried out to judge over a successful treatment. Additionally, the results in Table 5 and 6 indicate that exceeding the optimum soaking time will not detrimentally affect stretchability of cheese according to the time interval used in this study (8 weeks).

Effect of four selected emulsifier salts on $\mathrm{pH}$ changes of Nabulsi cheese from cow milk: The results in Table 7 shows that the shift of cheese $\mathrm{pH}$ was less than the nominal ranges given by the suppliers; this is obviously a result of the relatively low concentration $0.5(\mathrm{w} / \mathrm{w})$ used for our specific treatment. The usual concentration used for processed cheese is about 3$5 \%{ }^{[4]}$, i. e tenfold or more of that used in the experiments. The concentration of Puromelt $\mathrm{C} 1$ emulsifier salt caused a shift in $\mathrm{pH}$ from 6.6 to 7.6, while Monosodium phosphate reduced the $\mathrm{pH}$ from 6.6 to 6.4. It can be seen that the two most effective salts had quite different effects on the ultimate $\mathrm{pH}$ of the 
cheese. It is interesting to note that Monosodium phosphate reduced the $\mathrm{pH}$ of the cheese, whereas Puromelt C1 made it basic. This fact should be considered in studying the effect of such treatments on the keeping ability of the product in terms of microbial activity.

\section{CONCLUSION}

High levels of meltability and stretchability could be achieved in white brined cheese after 2 to 4 weeks of storage at room temperature through the addition of $0.2 \%$ (w/w) Puromelt C1 or Monosodium phosphate emulsifier salts to the original brine. The type of cheese significantly affects the meltability and stretchability values and cheese made from sheep milk gave the best results. Emulsifying salts need a specific time interval to reach the optimum values of meltability and stretchability. Monosodium phosphate reduced the $\mathrm{pH}$ of the cheese samples from 6.6 to 6.4 , whereas puromelt $\mathrm{C} 1$, which is a mixture of sodium citrate, sodium phosphate and sodium poly phosphate, made it basic (7.6). This fact should be considered in studying the effect of such treatments on the keeping ability of the product in terms of microbial growth. Further studies are needed to investigate these treatments on commercial cheese samples for production of some traditional dishes.

\section{ACKNOWLEDGMENT}

The researchers are thankful to Applied Science University for providing necessary technical and financial support throughout this study.

\section{REFERENCES}

1. Arnott, K.R., H.A. Morries and W.B. Combs, 1957. Effect of certain chemical factors on the melting quality of process cheese. J. Dairy Sci., 40: 957-963.

http://jds.fass.org/content/vol40/issue8/

2. Abu-Alruz, K. A.S. Mazahreh, J.M. Quasem, R.K. Hejazin and J.M. El-Qudah, 2009. Effect of proteases on meltability and stretchability of nabulsi cheese. Am. J. Agric. Biol. Sci., 4: 173-178. 2009.

http://www.scipub.org/fulltext/AJAB/AJAB43173178.pdf

3. Mazahreh, A.S., J.M. Quasem, A.S. AL-shawabkeh and A.I. Abdullah, 2009. The Effect of adjusting $\mathrm{PH}$ on stretchability and meltability to white brined
Nabulsi cheese. Am. J. Applied Sci., 6: 543-550. http://www.scipub.org/scipub/c4p.php?j_id=ajas

4. Sousaa, M.J., Y. Ardöb and P.L.H. McSweeney, 2001. Advances in the study of proteolysis during cheese ripening. Int. Dairy J., 11: 183-576. DOI: 10.1016/S0958-6946(01)00062-0

5. Gomes, A.M.P., M.M. Vieira and F.X. Malcata, 1998. Survival of probiotic microbial strains in a cheese matrix during ripening: Simulation of rates of salt diffusion and microorganism survival. J. Food Eng., 36: 281-301. http://cat.inist.fr/?aModele $=$ afficheN\&cpsidt $=2369$ 473

6. Humeid, H.A., S.K. Tukan and M.I. Yamani, 1990. In-bag steaming of white brined cheese as a method of preservation. Milk Sci. Int., 45: 513-516. http://www.khayma.com/tagthia/preservation.html

7. Al-Ruqaie, I.M., H.M. El-Nakhal and A.N. Wahdan, 1987. Improvement in the quality of the dried ferment milk product. Ogytt. J. Dairy R., 54: 429-435.

8. Kindstedt, P.S., 1993. Effect of manufacturing factors, composition and proteolysis on the functional characteristics of mozzarella cheese. Critical Rev. Food Sci. Nutr., 33: 167-173. http://www.fao.org/agris/search/display.do?f=./199 6/v2227/US9615812.xml;US9615812

9. Muthukumarappan, K., Y.C. Wang and K. Gunase, 1999. Short communication: Modified schreiber test for evaluation of mozzarella cheese melt ability. J. Dairy Sci., 82: 1068-1071. http://jds.fass.org/cgi/content/abstract/82/6/1068

10. Smith, C.E., Rosenau, J.R. and M. Peleg, 1980. Evaluation of the flowability of melted mozzarella cheese by capillary rheometry. J. Food Sci., 45: 1142-1145. DOI: $10.1111 / \mathrm{j} .1365-$ 2621.1980.tb06506.x

11. Scott, R., 1986. Cheese Making Practice. 2nd Edn., Elsevier Applied Science Publishers, London and New York.

12. Hong, W.H. and S.D. Wen, 2002. Melting characteristics of cheese: Analysis of effects of cooking conditions using computer vision technology. J. Food Eng., 51: 305-310. DOI: 10.1016/S0260-8774(01)00072-3 